\title{
Science Meets Traditional Knowledge: Water and Climate in the Sahtu (Great Bear Lake) Region, Northwest Territories, Canada
}

\author{
MING-KO WOO, ${ }^{1}$ PAUL MODESTE, ${ }^{2}$ LAWRENCE MARTZ, ${ }^{3}$ JOE BLONDIN,${ }^{2}$ BOB KOCHTUBAJDA, ${ }^{4}$ \\ DOLPHUS TUTCHO,${ }^{2}$ JOHN GYAKUM,${ }^{5}$ ALPHONSE TAKAZO,${ }^{2}$ CHRIS SPENCE,${ }^{6}$ JOHNNY TUTCHO,${ }^{2}$ \\ PETER DI CENZO, ${ }^{7}$ GEORGE KENNY,${ }^{2}$ JOHN STONE,${ }^{8}$ ISRAEL NEYELLE, ${ }^{2}$ GEORGE BAPTISTE, ${ }^{2}$ \\ MORRIS MODESTE, ${ }^{2}$ BRUCE KENNY ${ }^{2}$ and WALTER MODESTE ${ }^{2}$
}

(Received 13 October 2005; accepted in revised form 24 August 2006)

\begin{abstract}
In July 2005, several scientists from the Mackenzie GEWEX (Global Energy and Water Cycle Experiment) Study, known as MAGS, met with aboriginal people in Deline on the shore of Great Bear Lake to exchange information on climate and water in the region. Topics discussed pertained directly to the northern environment, and they included climate variability and change, wind, lightning, lake ice, lake level, and streamflow. The traditional knowledge shared by the residents is a rich source of local expertise about the landscape and climate systems of the Deline area, while the scientific knowledge provided by MAGS presents a scientific basis for many observed climate and water phenomena, particularly on a broad regional scale. Through cordial and open discussions, the meeting facilitated the sharing of traditional knowledge and scientific results. The meeting enhanced the potential for traditional knowledge to help direct and validate scientific investigations and for scientific knowledge to be used in conjunction with traditional knowledge to guide community decision making.
\end{abstract}

Key words: weather and climate, water resources, atmospheric science, hydrology, traditional knowledge, northern environment, Deline, Great Bear Lake

RÉSUMÉ. En juillet 2005, plusieurs scientifiques de l'étude Mackenzie GEWEX (expérience internationale sur l'énergie et le cycle hydrologique), connue sous le nom de MAGS, ont rencontré les Autochtones de Deline, sur la côte du Grand lac de l'Ours dans le but d'échanger des données sur les conditions climatiques et hydrologiques de la région. Les sujets à l'étude se rapportaient directement à l'environnement nordique, plus précisément la variabilité et le changement climatiques, le vent, la foudre, la glace lacustre, le niveau des lacs et le débit des cours d'eau. Les connaissances traditionnelles des habitants de la région représentent une riche source d'expertise locale au sujet du paysage et des systèmes climatiques de la région de Deline, tandis que les connaissances scientifiques fournies par MAGS constituent une base scientifique pour de nombreux phénomènes climatiques et hydrologiques observés, surtout sur une vaste échelle régionale. Grâce à des discussions cordiales et ouvertes, cette réunion a donné lieu au partage de connaissances traditionnelles et de résultats scientifiques. Cette réunion a également permis d'accroître la possibilité que les connaissances traditionnelles aident à diriger et à valider les enquêtes scientifiques, et que les connaissances scientifiques soient employées de pair avec les connaissances traditionnelles pour favoriser la prise de décisions au sein de la collectivité.

Mots clés : temps et climat, ressources hydrologiques, science de l'atmosphère, hydrologie, connaissances traditionnelles, environnement nordique, Deline, Grand lac de l'Ours

Traduit pour la revue Arctic par Nicole Giguère.

\section{INTRODUCTION}

Dené traditional knowledge is concerned with air, water, land, wildlife, people, and the ways in which these interact with one another. For millennia, people of Canada's Mackenzie
Basin have lived with, used, and learned about snow, ice, frost, lakes, and rivers in a cold climate (Deline First Nation, 2005). Water and climate are also the foci of scientific investigation by the researchers of the Mackenzie GEWEX (Global Energy and Water Cycle Experiment) Study, called

\footnotetext{
${ }^{1}$ School of Geography and Earth Sciences, McMaster University, Hamilton, Ontario L8S 4K1, Canada; woo@mcmaster.ca

${ }^{2}$ Deline Renewable Resources Council, P.O. Box 156, Deline, Northwest Territories X0E 0G0, Canada

${ }^{3}$ Department of Geography, University of Saskatchewan, Saskatoon, Saskatchewan S7N 5A5, Canada

${ }^{4}$ Hydrometeorology and Arctic Laboratory, Environment Canada, Edmonton, Alberta T6B 2X3, Canada

${ }^{5}$ Department of Atmospheric and Oceanic Sciences, McGill University, Montreal, Quebec H3A 2K6, Canada

${ }^{6}$ National Water Research Institute, Environment Canada, Saskatoon, Saskatchewan S7N 3H5, Canada

${ }^{7}$ MAGS Research Network, National Hydrology Research Centre, Saskatoon, Saskatchewan S7N 3H5, Canada

${ }^{8}$ Department of Geography and Environmental Studies, Carleton University, Ottawa, Ontario K1S 5B6, Canada

(C) The Arctic Institute of North America
} 
MAGS, a collaborative research network that conducted studies of the air and water in the Mackenzie Basin from 1994 to 2005 (Rouse et al., 2003). In July 2005, a delegation of MAGS scientists met with the community of Deline, Northwest Territories, to exchange information. The aim was to gain a better understanding of the atmospheric and water environments through a sharing of traditional and scientific knowledge.

One expectation of the Natural Sciences and Engineering Research Council (NSERC) of Canada, which partially funded the MAGS Network, was that the scientific team would communicate with communities and stakeholders in the research area. Initial communications with the Deline community (discussed in the following section) resulted in an invitation for more interactive discussion of the scientific findings of the MAGS study and their implications for the community. Community leaders also expressed a keen interest in exploring approaches to the environment that differ from those of traditional knowledge and in becoming more familiar with scientists and with scientific perspectives and research methods. The scientific team was motivated by the excitement of sharing the results of its study, the opportunity to learn from the experience of residents, and the potential of using local knowledge to validate their findings.

Scientific knowledge and traditional knowledge are based on different worldviews, use different methods for acquiring and disseminating knowledge, and usually focus on different spatial scales (Table 1, ANSC, 2005). Traditional knowledge is based on generations of keen observations and experiential understanding of the natural environment in the territory over which hunting, trapping, fishing, and social activities are carried out. MAGS scientific studies are regional in scope: they cover a territory of 1.8 million $\mathrm{km}^{2}$ and examine its atmospheric and hydrologic conditions over a 12-year time span (1993-2005), but they also use data from historical archives that can extend back over half a century. Information from local levels is invaluable to the validation of regional results. Also, a regional knowledge of the fluxes of heat and air and the flow of water offers a broad picture that enhances understanding of the local patterns of wind, ice, snow, and stream discharge. Traditional knowledge is integrative, considering the environment as a whole entity that provides physical as well as spiritual well-being to the people (Mackenzie Valley Environmental Impact Review Board, 2005). Western science, on the other hand, tends to take a reductionist approach, examining specific elements of the environment in depth.

Riedlinger and Berkes (2001:315) suggest that traditional knowledge can complement scientific knowledge by "the use of traditional knowledge as local scale expertise; as a source of climate history and baseline data; in formulating research questions and hypotheses; as insight into impacts and adaptation in Arctic communities; and for long term, community-based monitoring." The objectives of the MAGS-Deline meeting were to explore these potential
TABLE 1. Comparison of traditional and scientific knowledge styles (Reprinted with permission from ANSC, 2005).

\begin{tabular}{ll}
\hline \hline INDIGENOUS KNOWLEDGE & SCIENTIFIC KNOWLEDGE \\
\hline Assumed to be the truth & Assumed to be a best approximation \\
Sacred and secular together & Secular only \\
Teaching through storytelling & Didactic \\
Learning by doing and experiencing & Learning by formal education \\
Oral or visual & Written \\
Integrated, based on a whole system & Analytical, based on subsets of whole \\
Intuitive & Model- or hypothesis-based \\
Holistic & Reductionist \\
Subjective & Objective \\
Experiential & Positivist \\
\hline \hline
\end{tabular}

uses of traditional knowledge to enhance scientific understanding of the integrated climate and water system of the Mackenzie River Basin and to discuss the potential for this scientific understanding to complement aboriginal community knowledge systems at the local level.

MAGS can claim no special expertise in subjects other than the atmospheric and hydrologic sciences. Nevertheless, a meeting of MAGS scientists with the aboriginal people of Deline provided an invaluable opportunity for the direct exchange of information on climate and water between holders of traditional and scientific knowledge about a common area. This paper reports the dialogue between a community endowed with first-hand knowledge of the northern environment through its cultural heritage and livelihood and a group of scientists with considerable expertise on the climate and hydrology of cold regions. Its list of authors reflects the collaboration of MAGS scientists and Deline community representatives in its preparation.

\section{BACKGROUND}

Deline is located in the Northwest Territories of Canada at $65^{\circ} \mathrm{N}, 123^{\circ} \mathrm{W}$ (Fig. 1) at the western end of Keith Arm (Dahreli in North Slavey) on Great Bear Lake (Sahtu), close to where the Great Bear River (Sahtu De) flows from the lake. Deline was officially known as Fort Franklin until 1993, when the Sahtu Dené and Métis Comprehensive Land Claim Agreement was signed. That year the people of Deline reclaimed their own name for the community. In the North Slavey language, Deline means 'where the water flows' (a reference to the headwaters of the Great Bear River). Today it is a community of approximately 700 people, of whom $93 \%$ are Dené and Métis of Slavey heritage. The community is situated near the mouth of the Great Bear River, in a sheltered bay that was a traditional gathering place for people of the region long before the village was established.

There was considerable interaction between MAGS and the Deline community prior to the meeting in July 2005. In 2003 , the community was engaged to participate in snow and lake-ice investigations on Great Bear Lake. Six people from Deline were trained and hired to assist in setting up 


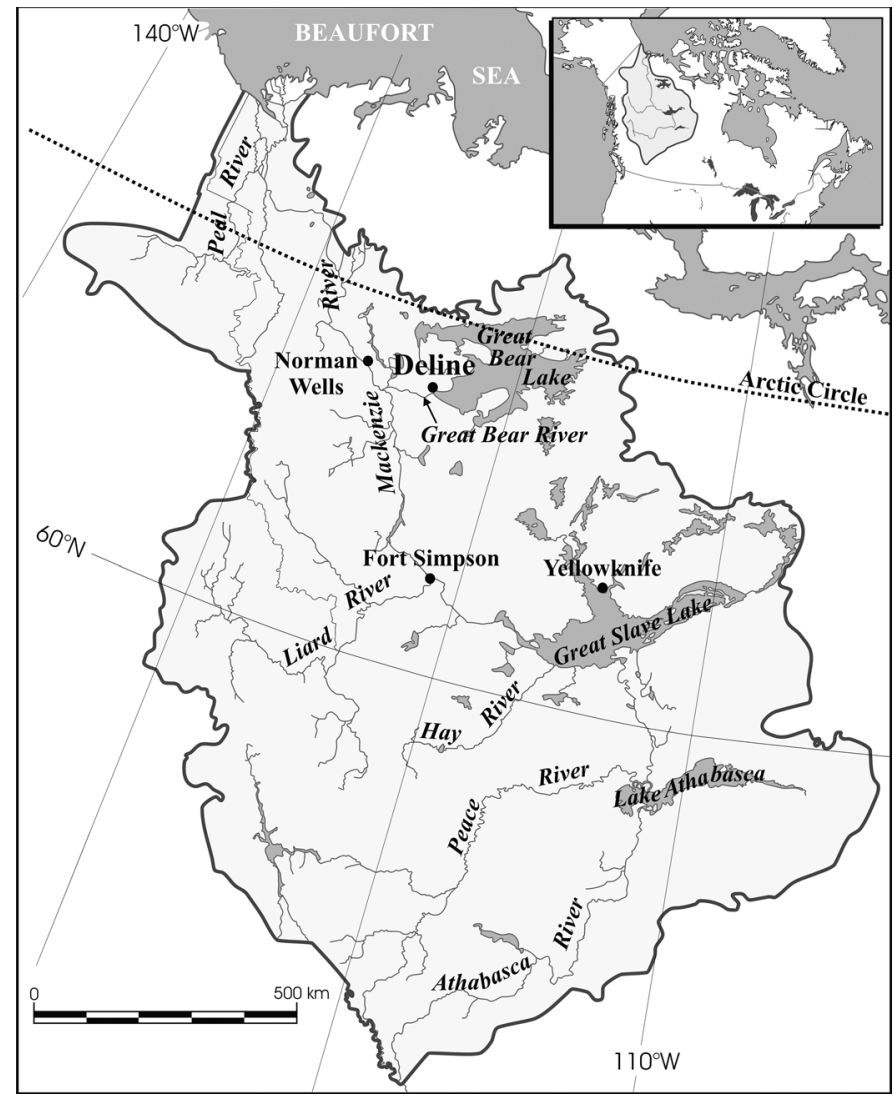

FIG. 1. Location of Deline in the Mackenzie River Basin. Inset shows size and location of the Basin relative to the rest of Canada.

field sites and making field observations. This capacitybuilding initiative was very successful and was extended through 2005 and 2006. MAGS representatives visited the community on three occasions (in May 2004, October 2004, and February 2005) to share knowledge through formal and informal presentations to various community groups, including the elders, community leaders, members of the Deline Renewable Resources Council (DRRC), the schools, and the general public. In addition, members of the DRRC attended and presented talks at scientiststakeholder meetings sponsored by MAGS.

The rapport established through these interactions generated interest in the community to hear more about MAGS research and resulted in a formal invitation for MAGS scientists to participate in a larger community meeting focused on two-way information sharing. Seven MAGS scientists and 15 Deline participants selected by the DRRC attended the meeting, held on 7-8 July 2005 . The DRRCselected participants included elders, DRRC members, people from the community who live and work on the land, and high school students, providing a good cross-section of the community. A local interpreter facilitated translations between English and North Slavey.

Designed to encourage interactive sharing of information and ideas, the meeting was structured around a series of informal presentations by scientists and community representatives. Their topics encompassed climate variability and change, wind, lightning, lake ice, lake level, and streamflow. These talks were interspersed with open-ended breakout sessions of scientists and community members. At the request of the community participants discussions were not taped, but participants took notes during the meeting. Quotations from community representatives (presented here in italics) were authenticated at the meeting and through manuscript review by our Deline co-authors.

The meeting began with a traditional prayer by a community elder, followed by a general discussion of traditional and scientific knowledge systems. MAGS scientists provided an overview of scientific inquiry, and Deline community elders outlined the nature and scope of traditional knowledge. Dené traditional knowledge was described as encompassing air, water, land, wildlife, and people, as well as the ways in which they interact, and as having an essential ethical and spiritual dimension that guides the way in which people interact with one another and with their environment. The significance of the differences between traditional and scientific understanding of the world were discussed. Several community participants observed that traditional knowledge systems are not static but evolve continuously by incorporating new information from a variety of sources, which can include scientific research.

\section{TOPICS ON CLIMATE AND WATER}

\section{Climate Warming and Variability}

The Mackenzie Basin has experienced the greatest warming in Canada during the last 50 years, and Deline is situated at the centre of a zone where mean annual temperature has risen by over $1.5^{\circ} \mathrm{C}$ since 1950 (Fig. 2). Instrumental records from Norman Wells and Fort Simpson (Fig. 1), the nearest stations with long-term records, further indicate that most of the warming occurred in the winter. If only the months of November to April are considered, both Norman Wells and Fort Simpson data showed an average temperature rise of $0.06^{\circ} \mathrm{C} /$ year (Fig. 3). Summer temperatures, however, show no apparent trend. The reported recent trend of global warming (ACIA, 2005) refers to the average condition for the entire globe, with considerable regional deviations from this general trend (Zhang et al., 2000). For example, from a regional perspective, warming in the western Arctic was paralleled by cooling in the eastern Arctic (Fig. 2).

\section{What was it like before 1950?}

This was a question raised at the meeting. Fort Simpson has an air-temperature record that goes back to the beginning of the 20th century. It can be seen from this instrument record (Fig. 4) that some years in the 1940s had warm conditions comparable to those of recent decades. This is not surprising, since the Earth's climate is driven by 


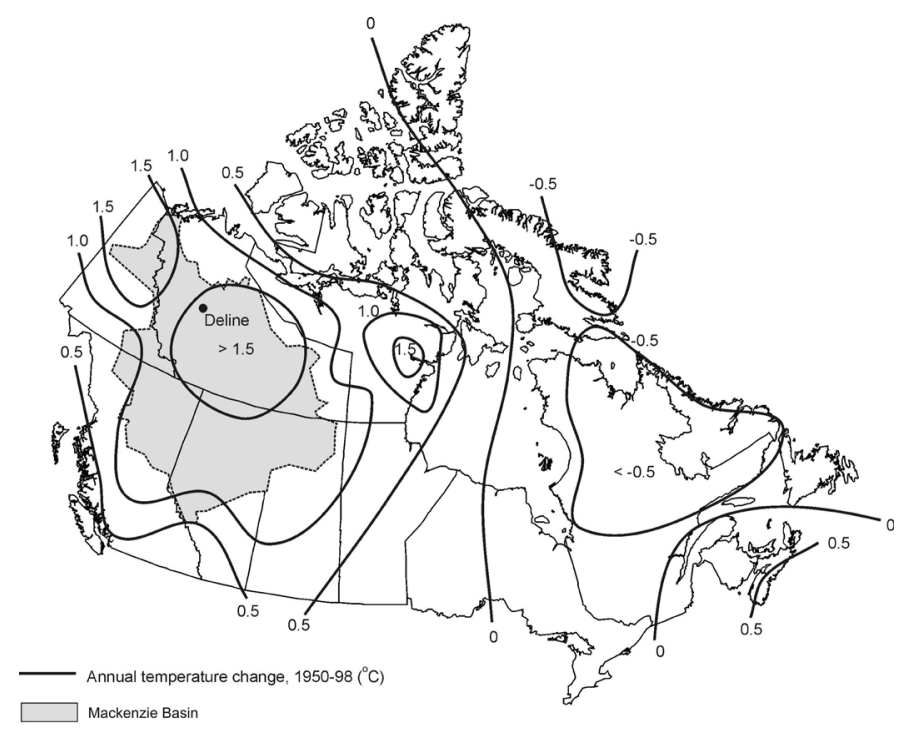

FIG. 2. Isolines showing the rise (in ${ }^{\circ} \mathrm{C}$ ) in mean annual temperature between 1950 and 1988 (adapted from a map provided by Environment Canada).

natural as well as by human forces. For instance, changes in radiation emission from the sun or major volcanic eruptions that disgorge water vapour and gases into the atmosphere can both induce regional or global variations in climate. On the other hand, human activities that since the industrial revolution have been producing an increasing amount of greenhouse gases, including carbon dioxide and methane, also affect the Earth's climate (IPCC, 2001).

One notable climatic feature is the large year-to-year variation in temperature. Climate models and observations indicate that the Mackenzie Basin has the largest interannual temperature variability in the Northern Hemisphere (Kistler et al., 2001). Traditional knowledge confirms that there are wide fluctuations in temperature. For example, 1998 was an exceptionally warm year, and the following year was cold again.

Ten yearsago, we hadintense cracking of the ice [formation of contraction cracks due to coldness] but not any more nowadays.

Community participants initially attributed this to climate change; more specifically, to winter warming. However, MAGS scientists noted that the complex relationship between ice cracking and air temperature can confound any direct linkage between the observed warming and ice cracking intensity. More information on the local scale (such as water temperature, ice thickness, snow cover, ice properties) is required to clarify the role of climate warming in reducing the formation of ice cracks.

Wind

The morning calm of July 7 was accompanied by numerous mosquitoes that, thankfully, were removed by a breeze that sprang up in midday. The phenomenon of an

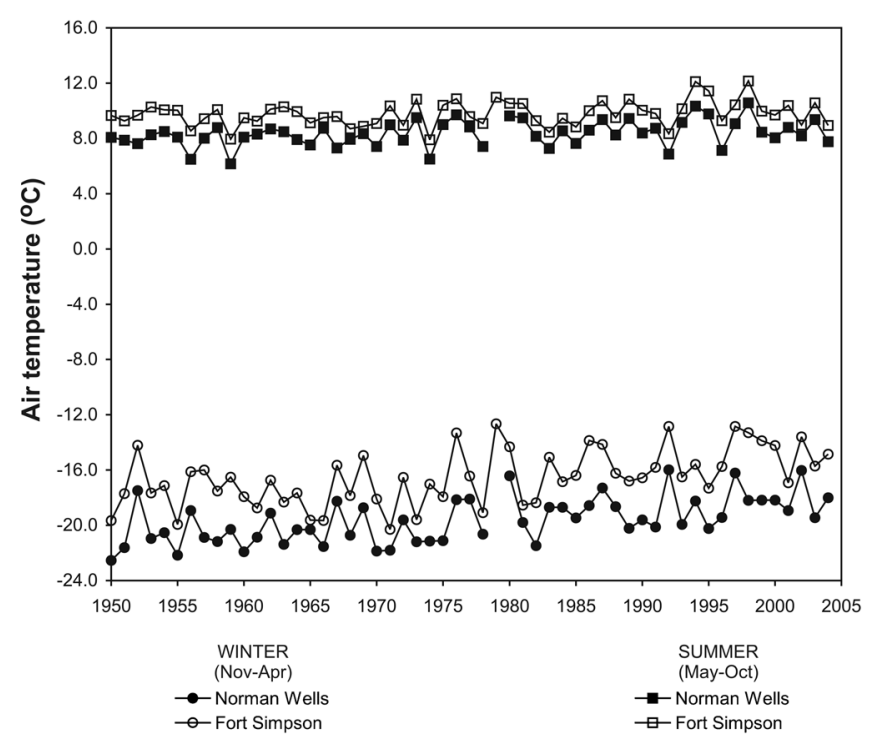

FIG. 3. Winter (November to April) and summer (May to October) air temperatures of Norman Wells and Fort Simpson between 1950 and 2004, suggesting a significant warming trend for winter but not for summer (Environment Canada, 2006).

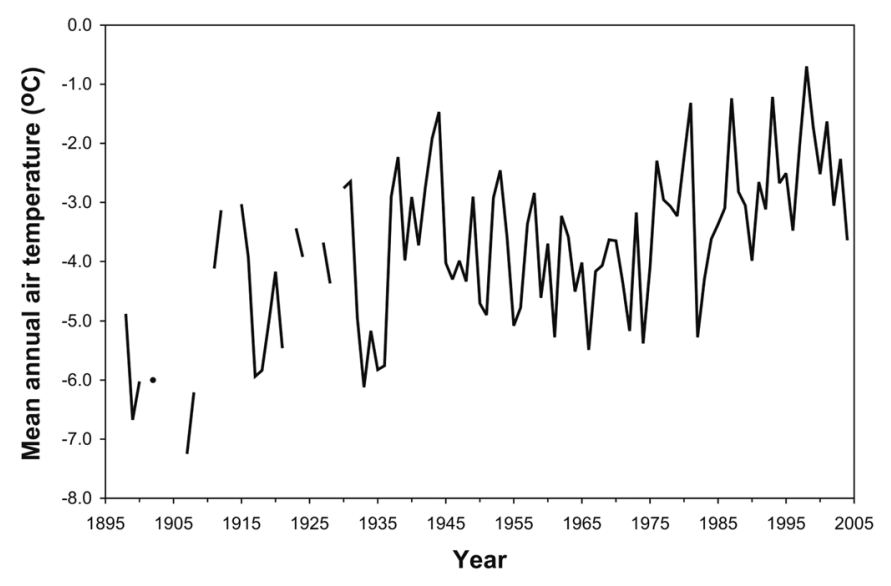

FIG. 4. Variation in mean annual air temperature at Fort Simpson during the 20th century. Gaps indicate missing data (Environment Canada, 2006).

afternoon breeze following a calm summer morning is well known in traditional knowledge:

This breeze is present not more than 4-5 km inland.

This is evidence of the sea-breeze effect generated by the large lake. In summer, the land is heated up more than the water. The rising hot air from the land is countered by the subsidence of cool air over the lake, setting up a convection cycle that drives the cool air onshore to replace the rising air. This sea breeze mechanism occurs within a short distance from the shore where land-water heating contrast is maintained, and it is effective only after differential heating has created the local convection (Schertzer and Croley, 1999). During days when the regional airflow is strong, local temperature contrasts are suppressed, and the sea breeze is replaced by the regional wind, as was experienced on July 8. 
Wind speed

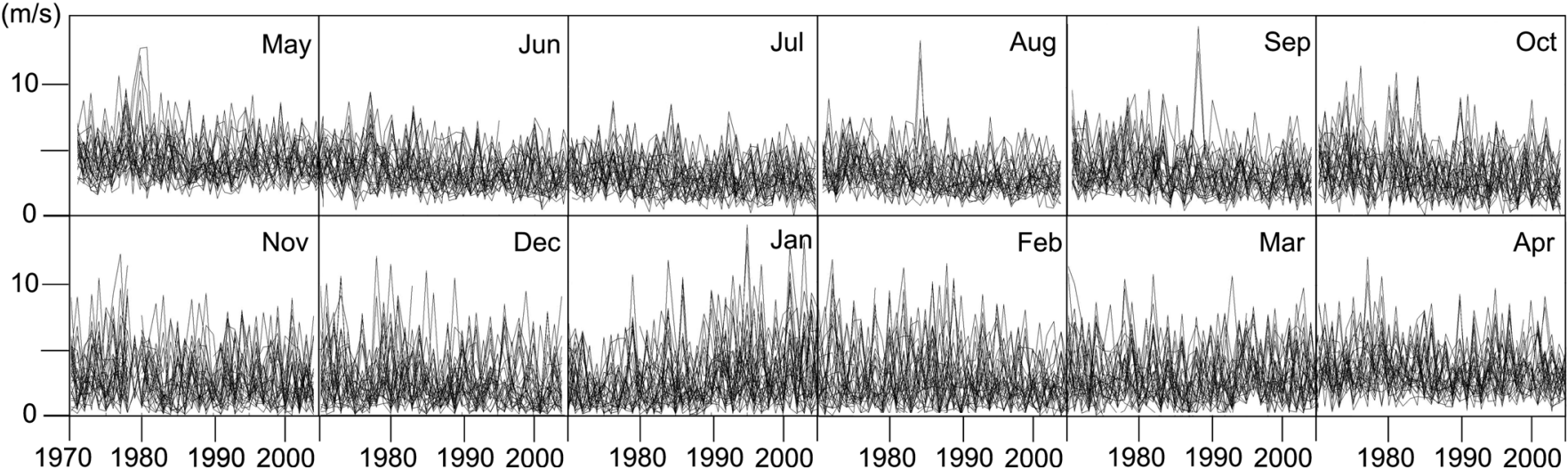

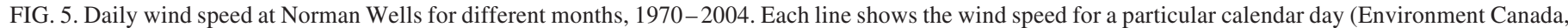
2006).

October is a windy period and we do not go out fishing in the lake.

The instrumental record from Norman Wells for the period 1970-2004 shows that wind speed tends to be lower in summer than in winter, as indicated in Fig. 5. Summer is generally a time of low winds, with wind speeds increasing in October and on into winter (although wind speeds continue to increase into winter, it is the October increase that is most noticeable to local people, as the lake is still ice-free and boats can still be used). Increased wind speeds in fall can be attributed to the southward advance of the cold continental Arctic air mass and increased frontal cyclonic activity (Burns, 1973). There has been a tendency for winter winds to diminish in recent years, especially the high winds, which now attain lower magnitudes than in the 1970s. This fact warrants further investigation but is beyond the scope of the present paper.

\section{Precipitation}

There was much snow last winter [2004-05]. Only the backside of caribou was seen above the snow.

Significant winter precipitation is often associated with the "pineapple express" (Lackmann et al., 1998; Lackmann and Gyakum, 1999), which is warm, moist subtropical air that flows northeastward from near the Hawaiian Islands to the West Coast of North America and across the Cordillera to reach the Mackenzie Basin (Fig. 6). This flow of subtropical air may produce large amounts of precipitation in the Basin.

Snow accumulation was not through heavy storms, but from many events.

Satellite imagery (NOAA-AVHRR) reveals the existence of a large band of snow in which the snow water equivalent was over $100 \mathrm{~mm}$ (snow water equivalent is the depth of the water obtained by melting a sample column of snow). This band recurs every winter and is aligned with the northern fringe of the boreal forest (Derksen and MacKay, 2006). Simulations using the Canadian Regional Climate Model suggest that frequent frontal activity in the late autumn and early winter is responsible for the snowfall events, depositing much snow on the northern boreal forest. Deline is located within this zone.

There was deep snow in the bush, but not on the muskeg.

We had rain last December. It froze with the snow. The caribou could not dig down to find food and moved to the southwest.

Snow drifting is common in open environments; therefore, the wetlands (or muskeg) would have less snow accumulation than the woodlands. Such a pattern of snow distribution is naturally important for wildlife and for human travel over snow in winter. Midwinter rain or snowmelt can deny wildlife access to its feed because rainwater and meltwater that percolate through the snow can freeze at the cold ground surface to form ice. The presence in the snow of ground-fast ice, which is hard for the caribou to dig through, often becomes an effective barrier to foraging (Miller et al., 1982).

\section{Lightning, Thunder, and Fire}

Lightning and thunder from cumulonimbus clouds are among the most spectacular natural phenomena on earth. The lightning mechanism within these thunderstorms is likened to shuffling one's feet across the carpet to acquire excess electrical charge, which is discharged by a spark when one touches another body. Lightning discharges have two key types: flashes between the cloud and the earth (cloud-to-ground discharges) and flashes within the cloud (intra-cloud discharges). Discharges can also occur from the cloud to the sky or between clouds, but these types are less frequent (Uman, 2001). 


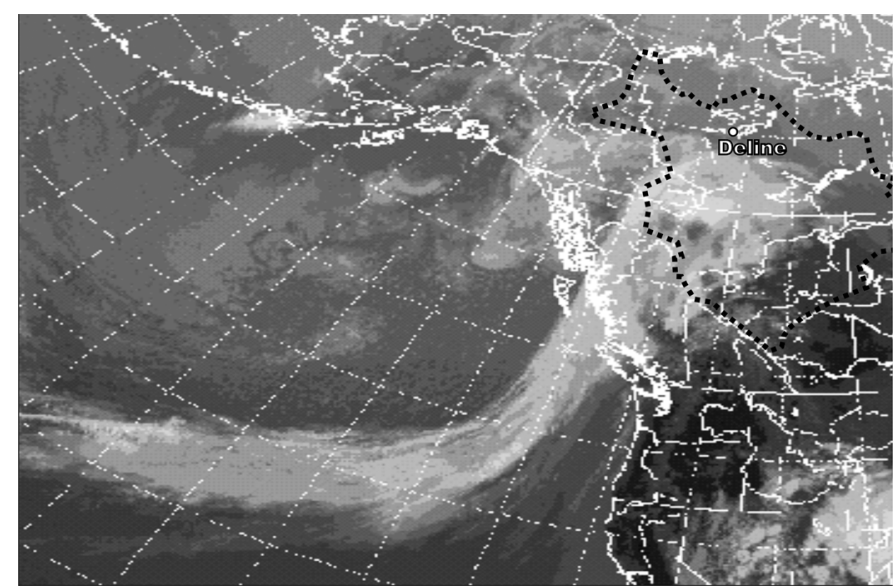

FIG. 6. Satellite image (NOAH - AVHRR) of the "pineapple express" for 25 April 1999, showing a band of precipitation-bearing clouds that extends from near Hawaii (lower left corner) to western Canada. The dotted line indicates the Mackenzie River Basin.

Lightning activity typically starts the majority of fires in the boreal forests of the Mackenzie Basin (Kochtubajda et al., 2002). Although fires are beneficial for controlling forest diseases and insects and for maintaining biological diversity, they affect the traditional land-based lifestyle by destroying habitat that is used for hunting, trapping, and harvesting berries and herbal medicines.

There was much lightning but less fire in the past.

[Thunder] used to be louder and stronger.

A rough rule of thumb for estimating the distance of the lightning source in kilometres is to count the seconds between the flash and the bang and divide by three (Few, 1975). Generally, thunder cannot be heard much more than $25 \mathrm{~km}$ from its source (Bhartendu, 1969), though several factors, including temperature gradients and wind shear in the atmosphere, can influence the range of audibility.

In the last 30 years, there are more fires and now the lightning is not so strong but there are more strikes.

The decadal changes in the number of large forest fires and areas burned within $100 \mathrm{~km}$ of the Deline community, obtained from the Large Fire Database (Stocks et al., 2002), are shown in Table 2. These data confirm the local observations. Between 1971 and 1998, 39 large fires (> 200 ha) burned nearly 350000 hectares. During the 1971-80 decade, four large fires consumed approximately 12000 hectares, but those numbers dramatically increased to 19 large fires and approximately 236000 hectares during 1991-98. Do these numbers suggest an increasing trend in lightning? Most forest fires in this region are lightning-initiated, but these disturbances also depend on such critical elements as available fuel (including dry leaves, twigs, and branches) and weather. Weather affects the ignition of fires through lightning, but it also influences fire behaviour: for example, strong winds, high
TABLE 2. Three decades of fire activity within a $100 \mathrm{~km}$ radius of Deline (Data source: CWFIS, 2006).

\begin{tabular}{lcc}
\hline \hline & Number of Fires & Area Burned (ha) \\
\hline $1971-80$ & 4 & 11565 \\
$1981-90$ & 16 & 94095 \\
$1991-98$ & 19 & 235856 \\
\hline \hline
\end{tabular}

temperatures, low humidity, and precipitation influence the rate of fire growth.

Data from the Northwest Territories lightning detection network for the summer seasons (June to September) of 1994-2002 were used to examine lightning behaviour within a $25 \mathrm{~km}$ radius of Deline (Table 3 ). Several observations can be made. On average, about 72 cloud-toground strikes were detected within the Deline area each year during 1994-2002, and these occurred on ten days. However, lightning activity can vary greatly from one year to the next. Nearly half of the seasonal lightning in the area can usually be attributed to the storms from one day. Lightning strikes within $5 \mathrm{~km}$ of the community are rare. The majority of lightning during the study period occurred more than $10 \mathrm{~km}$ away. The average distance was about $19 \mathrm{~km}$ from the community, which is near the outer limit of the area where thunder is still audible.

\section{Lake Ice}

The process of ice formation on large lakes is generally well understood by Western science. Once the water cools to below freezing, ice forms first on the shore or border, which is more protected from high winds that could disturb the freezing process (Gerard, 1990). Traditional knowledge describes how these processes are manifested on Great Bear Lake.

\section{The Arms of Great Bear Lake freeze first, and middle of the lake does not freeze up until December.}

\begin{abstract}
In the last winter [2004-05], November was calm and ice was able to form quickly across Great Bear Lake. Previously, the winds were strong and they drove the ice around, pushing it to the shore and piling up ice ridges with slush; but the last time we saw such ridges was in 1984.
\end{abstract}

Satellite imagery (AMSR - $89 \mathrm{GHz}$ images) clearly indicates rapid freeze-up of the lake between 7 and 17 November in 2004. The map in Fig. 7, for 18:00 MDT on 10 November 2004, illustrates the meteorological conditions typical for this 10-day period of freeze-up. At this time, Great Bear Lake was situated in a region of very weak winds (less than 5 knots) and under a strong ridge of high pressure with anomalously cold air. This extended period of cold, nearly calm conditions permitted an extensive ice cover to develop across the lake without blowing the initially formed ice towards sheltered embayments. 
TABLE 3. Cloud-to-ground lightning discharges within a $25 \mathrm{~km}$ radius of Deline (Original lightning data provided by R. Lanoville, Forest Management Division, GNWT.)

\begin{tabular}{|c|c|c|c|c|c|c|c|c|c|c|}
\hline & 1994 & 1995 & 1996 & 1997 & 1998 & 1999 & 2000 & 2001 & 2002 & $\begin{array}{c}\text { 1994-2002 } \\
\text { Average }\end{array}$ \\
\hline Total strikes & 31 & 28 & 117 & 82 & 104 & 55 & 86 & 50 & 93 & 71.8 \\
\hline Lightning days & 7 & 5 & 14 & 14 & 13 & 6 & 15 & 7 & 10 & 10.1 \\
\hline Strikes within $1 \mathrm{~km}$ & 0 & 0 & 0 & 1 & 0 & 0 & 2 & 1 & 0 & 0.44 \\
\hline Strikes within $5 \mathrm{~km}$ & 1 & 1 & 3 & 7 & 4 & 0 & 8 & 1 & 7 & 3.6 \\
\hline Strikes within $10 \mathrm{~km}$ & 3 & 6 & 17 & 22 & 20 & 2 & 13 & 11 & 19 & 12.6 \\
\hline Percentage of strikes, $10-25 \mathrm{~km}$ & 90.3 & 78.6 & 85.5 & 73.2 & 80.8 & 96.4 & 84.9 & 78.0 & 79.6 & 83.0 \\
\hline Average distance of lightning, $10-25 \mathrm{~km}$ & 20.0 & 19.6 & 18.6 & 18.4 & 17.9 & 18.7 & 19.6 & 18.4 & 17.4 & 18.7 \\
\hline Maximum 1-day lightning strikes & 9 & 11 & 74 & 29 & 40 & 35 & 41 & 27 & 66 & 36.9 \\
\hline 1-day strikes, percentage of seasonal total & 29.0 & 39.3 & 63.2 & 35.4 & 38.5 & 63.6 & 47.7 & 54.0 & 71.0 & 49.1 \\
\hline
\end{tabular}

Furthermore, the relationship between snow depth and ice thickness becomes apparent as the winter progresses:

More snow is warmer climate; ice thickness is less. Less snow is colder climate; ice thickness is greater.

Two sets of snow depth measurements and lake-ice thickness measurements made through ice-auger holes in Keith Arm of Great Bear Lake in late March show that the ice thickness reached $137 \mathrm{~cm}$ in March 2004 and $88.5 \mathrm{~cm}$ in March 2005. The snow depths were $17 \mathrm{~cm}$ in March 2004 and $26 \mathrm{~cm}$ in March 2005. Insulating properties of snow affect the chilling of lake water; thus, the deeper the snow, the thinner the lake ice (Gerard, 1990; Duguay et al., 2003). Local observations by Deline elders point to a decrease of ice thickness from 8 feet $(2.4 \mathrm{~m})$ in the past to about 6 feet $(1.8 \mathrm{~m})$ in recent winters. This decrease may suggest warmer winters (Fig. 3), but it could also indicate more snow accumulation. For example, Zhang et al. (2000) found an increase in snowfall amounts north of $55^{\circ} \mathrm{N}$.

There is a societal advantage to using traditional knowledge about the lake ice of Great Bear for winter travel:

\section{In a fog on the lake ice, traditional knowledge tells you not to follow the snow drifts but to drive across them. Some young men did not heed this and drove their skidoos along the snow drifts, only to plunge into open water at the outlet of the lake.}

The traditional knowledge of ice processes is an important consideration in traveling and fishing. Normally, open-water conditions may persist near the mouth of the lake. Elders noted that the predominant winds at Deline over winter are from the east, and these would create snowdrifts that point to the lake outlet.

\section{The ice usually goes out in Keith Arm in late June/early July, and it was unusual that the ice stayed until late July in 2004.}

During the two seasons when MAGS conducted a field study of Great Bear Lake, ice breakup was late in 2004 (July 27) but early in 2005 (June 14). Duguay et al. (2006)

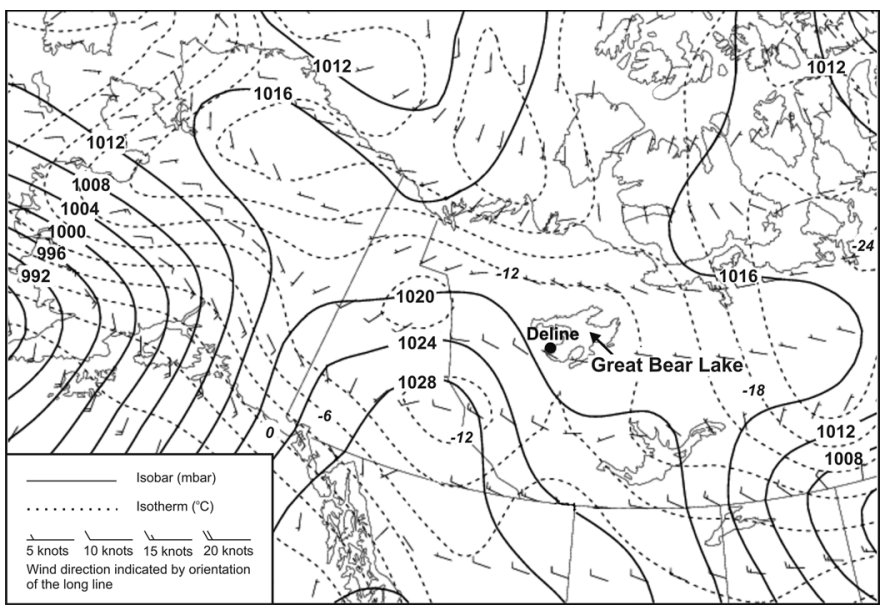

FIG. 7. Wind conditions on 10 November 2004, according to National Centers for Environmental Prediction (NCEP) Reanalysis, indicating the low wind speed of westerly air flow across the Great Bear Lake region. Isolines show mean sea-level pressure pattern (in mbar).

have examined freeze-up and breakup dates for selected lakes in the Mackenzie Basin, but could not find any statistically significant trends. It is likely that any trend, if present, was masked by large interannual variability as exemplified by the 2004 and 2005 breakup events.

Several factors influence the rate and duration of ice melt. Ice thickness is an obvious consideration (Ashton, 1983). While clear ice permits greater penetration of radiation to effect internal melt (Gerard, 1990), dirty ice has lower albedo to enhance surface ablation. Shore ice melt is accelerated by runoff from the land, and a floating ice cover is prone to attrition when the wind drives ice floes to crash against each other or crush against the shore (Heron and Woo, 1994). It may be that the ice thickness, weather, and runoff inputs offered favourable conditions for a late breakup in 2004.

\section{Lake Level and Streamflow}

For many generations, the people living in the region have relied on Great Bear Lake both for transportation, by boat in summer and over the ice in winter, and as a source of food:

The lake is our supermarket. 
The lake goes up and down every year. We do not notice much change in its level over the years.

It is normal for lake levels to fluctuate annually and seasonally in response to precipitation and temperature and over shorter periods because of storm surges or wind buildup when strong winds blow along long fetches (Schertzer and Croley, 1999). There is a pronounced seasonal rhythm in the fluctuation of Great Bear Lake, with minimum water levels occurring in April at the end of the cold season and before spring melt occurs (Fig. 8). Snowmelt and precipitation during the spring and summer contribute to rising levels, which peak in August or September. Decreasing input of water into the lake during fall and winter, accompanied by continuous lake discharge into the Great Bear River, produces a steady decline in lake level, which reaches its annual minimum at the end of winter.

Precipitation and temperature predominate as factors responsible for interannual variability in lake level (Schertzer and Croley, 1999). A year with high precipitation and lower temperature results in wet conditions that raise the lake level, so that a sequence of wet years will produce a rising trend. Conversely, a series of dry years causes the lake level to drop from year to year. When a sequence of wetter years alternates with a sequence of dryer years, the result is a cyclic pattern of annual lake level like that exhibited by Great Bear Lake (Fig. 8). These long-term tendencies are often masked by the within-year variability $(0.2-0.4 \mathrm{~m})$, so that the multi-year trend can be detected only through the instrumental records of the lake level.

A comparison of a three-year period with relatively low average lake level (1988-90) with a three-year period of relative high average lake level (2001-03) yields a difference of $0.16 \mathrm{~m}$. Such a difference in water level translates into a large change in lake volume, considering that Great Bear is among the 10 largest lakes in the world, with a surface area of over $31500 \mathrm{~km}^{2}$. A difference of $0.16 \mathrm{~m}$ is equivalent to a change in lake volume of $5.04 \mathrm{~km}^{3}$. A continued trend of lake level drop (or rise) can lead to a decline (or increase) in lake outflow, which, in turn, affects the discharge of the Great Bear River.

The residents of Deline are most familiar with the flow regime of rivers in the area.

Several years ago, engineers built a bridge across Porcupine River, a tributary of Great Bear River, without reference to traditional knowledge. The river crossing site was examined in the summer during low flow conditions and the bridge was erected at that crossing point. Came spring and the snowmelt runoff washed the bridge down the river, costing much money to bring it out.

The Porcupine River follows a nival streamflow regime (Woo, 2000), in which snowmelt produces high flows that can be orders of magnitude larger than the summer discharge.

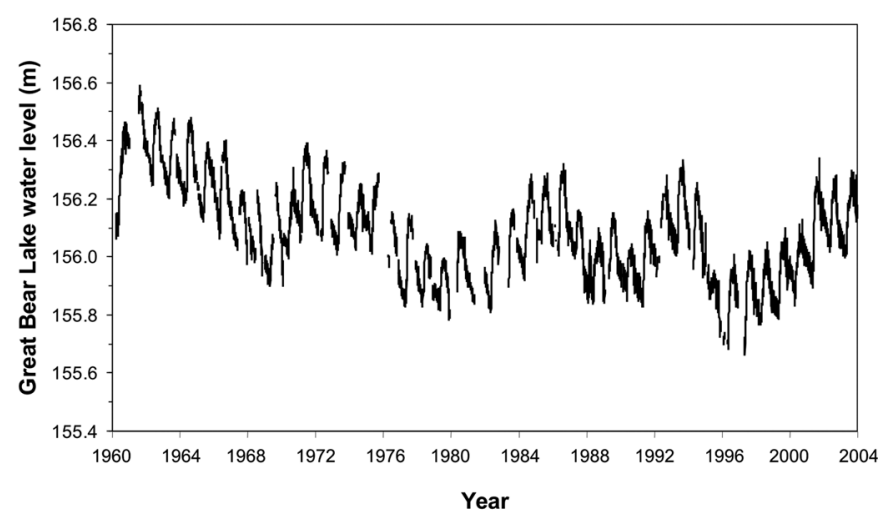

FIG. 8. Mean daily water level of Great Bear Lake, 1960-2004 (Water Survey of Canada, 2006).

Future engineering designs can benefit from consultation with local residents, whose traditional knowledge can provide insight not available from brief visits to the sites.

\section{CONCLUSION}

This paper documents a meeting of scientists and representatives of an aboriginal community for the purpose of direct information exchange and communication. Traditional knowledge as a source of local-scale expertise about the regional landscape and climate systems is especially valuable. The elders of the community have in-depth knowledge of the lake and land resources and the way these are linked to climatic phenomena. A number of interesting points raised in these discussions suggest research hypotheses that could be investigated jointly, using both scientific techniques and traditional knowledge.

A major goal of the meeting was to communicate the principal MAGS research findings of interest to the community, those concerning climate and water resource phenomena. Scientific knowledge was not generally seen as supplanting traditional knowledge, but rather as a useful source of additional information that complements traditional empirical information and can be applied within a traditional moral and ethical framework. During the meeting, a participant expressed the view that the community knowledge system continuously incorporates new information from scientific and other sources to build upon its traditional foundations. This underscores the importance of making research results accessible through appropriate publication and direct dialogue between scientific and traditional knowledge keepers.

Discussions about the physical environment proved to be an effective vehicle through which to conduct knowledge exchange. Both parties acknowledged an initial lack of familiarity with each other's knowledge base. The meeting demonstrated the value of direct dialogue in providing scientists with an appreciation of the richness and importance of traditional knowledge and in providing community members with an understanding of the scope, relevance, and reliability of scientific studies. All participants were pleased with the 
cordial and open nature of the information exchange. The consensus was that the Deline meeting had enhanced the potential for traditional knowledge to help direct and validate scientific investigations and for scientific knowledge to be used in conjunction with traditional knowledge to guide community decision making. The outcome of this direct dialogue leads us to recommend strongly that such opportunities continue to be pursued.

\section{ACKNOWLEDGEMENTS}

We thank the Natural Sciences and Engineering Research Council of Canada and Environment Canada for support; and we acknowledge the Deline Renewable Resource Council for invaluable contributions.

\section{REFERENCES}

ACIA (ARCTIC CLIMATE IMPACT ASSESSMENT). 2005. Arctic climate impact assessment: Scientific report. Cambridge: Cambridge University Press. 1042 p.

ANSC (ALASKA NATIVE SCIENCE COMMISSION). 2005. What is traditional knowledge? http://www.nativescience.org/ $\mathrm{html} /$ traditional_and_scientific.html.

ASHTON, G.D. 1983. Lake ice decay. Cold Regions Science and Technology 8:83-86.

BHARTENDU. 1969. Thunder-a survey. Le Naturaliste Canadien 96:671-681.

BURNS, B.M. 1973. The climate of the Mackenzie Valley Beaufort Sea. Vol. I. Climatological Studies Number 24. Toronto, Ontario: Environment Canada.

CWFIS (CANADIAN WILDLAND FIRE INFORMATION SYSTEM). 2006. Historical analysis: Large fire database point version. Edmonton: Canadian Forest Service. http:// cwfis.cfs.nrcan.gc.ca/en/historical/ha_lfdb_maps_e.php.

DELINE FIRST NATION, 2005. Dené ways of respecting the land and animals. Final report on traditional knowledge and natural resource management. Submitted by the Deline First Nation to the Sahtu Renewable Resources Board, July 2005. Available from Deline Renewable Resources Council, P.O. Box 156, Deline, Northwest Territoires X0E 0G0. 25 p.

DERKSEN, C., and MACKAY, M. 2006. The Canadian boreal snow water equivalent band. Atmosphere-Ocean 44:305-320.

DUGUAY, C.R., FLATO, G.M., JEFFRIES, M.O., MENARD, P., MORRIS K., and ROUSE, W.R. 2003. Ice cover variability on shallow lakes at high latitudes: Model simulations and observations. Hydrological Processes 17:3465-3483.

DUGUAY, C.R., PROWSE, T.D., BONSAL, B.R., BROWN, R.D., LACROIX, M.P., and MENARD, P. 2006. Recent trends in Canadian lake ice cover. Hydrological Processes 20: 781-801.

ENVIRONMENT CANADA. 2006. Climate data online. http:// www.climate.weatheroffice.ec.gc.ca/prods_servs/index_e.html. FEW, A.A. 1975. Thunder. Scientific American 233:80-90.
GERARD, R. 1990. Hydrology of floating ice. In: Prowse, T.D., and Ommanney, C.S.L., eds. Northern hydrology: Canadian perspectives. National Hydrology Research Institute Science Report No. 1. 103-134.

HERON, R., and WOO, M.K.1994. Decay of a High Arctic lake ice cover: Observations and modelling. Journal of Glaciology 40:283-292.

IPCC (INTERGOVERNMENTAL PANEL ON CLIMATE CHANGE). 2001. Climate change 2001: The scientific basis. Contribution of Working Group I to the Third Assessment Report of the Intergovernmental Panel on Climate Change. Edited by Houghton, J.T., Ding, Y., Griggs, D.J., Noguer, M., van der Linden, P.J., Dai, X., Maskell, K., and Johnson, C.A. Cambridge: Cambridge University Press. 881 p.

KISTLER, R., KALNAY, E., COLLINS, W., SAHA, S., WHITE, G., WOOLLEN, J., CHELLIAH, M., EBISUZAKI, W., KANAMITSU, M., KOUSKY, V., VAN DEN DOOL, H., JENNE, R., and FIORINO, M. 2001. The NCEP-NCAR 50-year reanalysis: Monthly means CD-ROM and documentation. Bulletin of the American Meteorological Society 82:247-267.

KOCHTUBAJDA, B., STEWART, R.E., GYAKUM, J.R., and FLANNIGAN, M.D. 2002. Summer convection and lightning over the Mackenzie River Basin and their impacts during 1994 and 1995. Atmosphere-Ocean 40:199-220.

LACKMANN, G.M., and GYAKUM, J.R. 1999. Heavy coldseason precipitation in the northwestern United States: Synoptic climatology and an analysis of the flood of 17-18 January 1986. Weather Forecasting 14:687-700.

LACKMANN, G.M., GYAKUM, J.R., and BENOIT, R. 1998. Moisture transport diagnosis of a wintertime precipitation event in the Mackenzie River Basin. Monthly Weather Review 126:668-691.

MACKENZIE VALLEY ENVIRONMENTAL IMPACT REVIEW BOARD. 2005. Guidelines for incorporating traditional knowledge in environmental impact assessment. 42 p. http:// www.mveirb.nt.ca/reference_lib/guidelines.php.

MILLER, F.L., EDMONDS, E.J., and GUNN, A. 1982. Foraging behaviour of Peary caribou in response to springtime snow and ice conditions. Canadian Wildlife Service Occasional Paper No. $48.41 \mathrm{p}$.

RIEDLINGER, D., and BERKES, F. 2001. Contributions of traditional knowledge to understanding climate change in the Canadian Arctic. Polar Record 37:315-328.

ROUSE, W.R., BLYTH, E.M., CRAWFORD, R.W., GYAKUM, J.R., JANOWICZ, J.R., KOCHTUBAJDA, B., LEIGHTON, H.G., MARSH, P., MARTZ, L., PIETRONIRO, A., RITCHIE, H., SCHERTZER, W.M., SOULIS, E.D., STEWART, R.E., STRONG, G.S., and WOO, M.K. 2003. Energy and water cycles in a high-latitude, north-flowing river system. Bulletin, American Meteorological Society 84:73-87.

SCHERTZER, W.M., and CROLEY, T.E., II. 1999. Climate and lake responses. Chapter 2. In: Lam, D.C.L., and Schertzer, W.M., eds. Potential climate change effects on Great Lakes hydrodynamics and water quality. Reston, Virginia: American Society of Civil Engineers Press. 2.1-2.74. 
STOCKS, B.J., MASON, J.A., TODD, J.B, BOSCH, E.M., WOTTON, B.M., AMIRO, B.D., FLANNIGAN, M.D., HIRSCH, K.G., LOGAN, K.A., MARTELL, D.L., and SKINNER, W.R. 2002. Large forest fires in Canada, 19591997. Journal of Geophysical Research; doi: 10.1029/ 2001JD000484.

UMAN, M.A. 2001. The lightning discharge. Mineola, New York: Dover Publications, Inc. 377 p.
WATER SURVEY OF CANADA. 2006. Surface water and sediment data. http://www.wsc.ec.gc.ca/products/main_e.cfm? cname $=$ products_e.cfm.

WOO, M.K. 2000. Permafrost and hydrology. In: Nuttall, M., and Callaghan, T.V., eds. The Arctic: Environment, people, policy. Amsterdam: Harwood Academic Publishers. 57-96.

ZHANG, X., VINCENT, L.A., HOGG W.D., and NIITSOO, A. 2000. Temperature and precipitation trends in Canada during the 20th century. Atmosphere-Ocean 38:395-429. 